\title{
The Impact of Russian Educational Policy on the Formation of Georgian Education System
}

\section{Lana Kurashvili, PhD student}

Grigol Robakidze University, School of Public Administration and Politics, Georgia

\section{Doi:10.19044/esj.2020.v16n25p1 ～URL:http://dx.doi.org/10.19044/esj.2020.v16n25p1}

\begin{abstract}
The study examined the impact of Russian educational policy on the development of the education system in Georgia. It determines the factors influencing formation of the Georgian educational system for centuries under Tsarist and Soviet Russia. Despite years of reforms since independence, the issue of reorganizing the Georgian education system and eliminating the legacy of the past has not lost its relevance in the current period. The historical research method was used in order to study, analyze and draw specific conclusions from past events. The article presents the four main periods of Tsarist Russia and the first independent republic of Georgia in 1918-1921, the Soviet Union and modern independent Georgia. The mentioned periods were examined in the four main directions - the importance of education, national language policy, management system and teaching-learning approaches. The research has found that tsarist and Soviet authorities used similarly totalitarian-authoritarian methods to achieve imperial or Soviet party goals. An important difference concerned the importance of education when, unlike the Tsarist one, the Soviet authorities imposed a large mission on education, but in return demanded the existence of an ideologized society. As for the first independent republic of Georgia of 1918-1921 and the educational policy of modern independent Georgia, the educational policies of the mentioned periods coincide in regard of Western values, democratic principles and European approaches to teaching and learning. The educational policy of independent Georgia was characterized by a radical nature aimed at liberating the old school traditions and integrating them into the international educational space.
\end{abstract}

Keywords: Russian educational policy, Georgian education system, national language policy, Tsarist Russia, Soviet Union 


\section{Introduction}

The Georgian education system has undergone a political influence of the tsarist empire on the one hand and the Soviet Union on the other being as part of Russia for two centuries. Launching from Tsarist Russia to the first independent republic of Georgia in 1918-1921 and later from Soviet Union to the modern Georgia, the Georgian and the Russian educational policies replaced one another. Georgia is still under the urgent educational reform processes and is extremly trying to release itself from the past heritage and move to the modern educational standards. Therefore, it is important to identify the main areas of interest of Tsarist and Soviet educational policies, to identify common and distinctive features, strategies and motives for action. As this will help us to find argumentative explanations for the challenges facing the ongoing educational reforms in Georgia. The findings will be an important support for decision makers to implement the proper strategic changes.

The historical research method was used in the research process. Data collection, organization, analysis, and synthesis have been used to interpret, evaluate, and draw conclusions from past events. The primary and secondary historical sources were studied thoroughly. Georgian and foreign legislative documents were studied through desk research. Due to the limitations of historical research, there has been a shortage of articles published in the modern period, so the research materials are dominated by archival documentary materials and old periodicals.

The article presents four periods of formation of educational policy: the periods of Tsarist Russia and the periods of the first independent republic of Georgia in 1918-1921, the Soviet Union and the modern Georgia. Important events that influenced the development of Georgian educational policy have been studied. The main aspects of the research are the study of the importance of education, state language policy, management system and the philosophical-theoretical approaches to teaching and learning in the presented periods.

\section{The Russificationist policy of education}

As a result of the unification of Georgia under the auspices of the Russian Empire, the country's educational policy fell victim to the Russificationist policy of Tsarism. It should be noted that during the formation of the state education system in Europe, Georgia was involved in the struggle for self-preservation and, therefore, failed to bring the prevailing trend in Europe to the reality of Georgia. The introduction of public school education in Georgia coincides with the period of the country's stay in the Russian Empire. 
Issues related to the spread of education among the population in the Russian Empire went in a different direction from the European one. Although school education in Russia was imported from the West, Western values, generated by the movements of medieval humanist, Renaissance, and Protestant reformers, did not reflect Russian educational policy (Roucek, 1958). Education in the Russian Empire was only available to the upper classes. It was believed that low-class education was unacceptable, and that the mass spread of education would lead to a change in the existing social order. Due to this approach, millions of children in the Russian Empire did not even have an eye on school and millions of people did not have the ability to read and write (IQASGA, 2008).

The policy of the Russian Empire towards its member states was manifested in the Russificationist policy of Tsarism. The strategy is based on Slavic people's theory of idealization. Russia pursued a policy of alienation of its constituent peoples, seeking to obtain Russian from these peoples - "by language, customs and views" (Roucek, 1958). Due to this purpose, the publication of books and magazines in the state language was banned and, moreover, the native language was expelled from schools. Tsarism carried out the complete Russification of education in Georgia by replacing Georgian teachers with Russian chauvinists and by introducing a "dumb" method of teaching Russian (GHE, 1972, pp. 710-715). However, a decision was later made after the revolution to nationalize educational institutions when teaching in the mother tongue was allowed if the parents so wished (Karichashvili, 1917, pp. 345-347), which the current government used to influence less educated parents. The issue of the Georgian language was brought to the forefront of the national self-determination of Georgians, and therefore, the greatest struggles were fought over the production of education in the Georgian language. The Literacy Society of Georgia has made a significant contribution to this struggle, whose representatives have selflessly fought not only for the strengthening of the Georgian language, but also for the awakening of the national spirit in the Georgian society, the formation of the Georgian national pedagogical thought and the development of the national education system.

The activities of Georgian teachers, writers and public figures were aimed at understanding the future generation's education and, in general, the importance of education among the population. Georgian educators argued that lack of education was morally corrupting youth and throwing them into unbearable social conditions. Therefore, Akaki Tsereteli imagined the formation of high civic qualities only through education "but education real, true and not the kind of falsehood that we have received"(Oboladze, 1953). Georgian educators radically opposed the strict regime in Georgian schools during Tsarist Russia, the practice of listening, the acquisition of theoretical 
knowledge, the neglect of the child's nature, and the prevailing methods of corporal punishment of students. Under Tsarist Russia, parents preferred to remove their children from school because, according to Akaki Tsereteli, "a child can no longer learn, his brain is twisted and twisted" and "morality is ruined" (Oboladze, 1953).

Tsarist Russia was pursuing a classical, class, conservative educational course and using education as a means of social control. The autocratic style of governing the Russian Empire also influenced the organization of the education system. Democratic and tyrannical policies of the Russian emperors pursued democratic ideas, including education. Nicholas II maintained the current regime at all costs, "severely persecuting and destroying all forms of liberalism" (Laskhishvili, 1928, p. 45). This policy also affected the countries under the Russian Empire: "Unfortunately, the government in Russia has always hindered the study and education. The Russian government did not want to establish itself in the desired level of public education even in Russia, and the situation in the so-called bordering countries was extremely unbearable." (Laskhishvili, 1918, pp. 70-72).

The above-mentioned factors have had a great impact on the development of school education in Georgia. However, it is worth to mention that the vicious sides of the presented reality were loudly exposed and selflessly fought for their correction by Georgian educators who tried to spread the importance of education and, more importantly, the democratic principles of education, nationalism, humanism and harmonious development of personality in the Georgian society.

\section{Educational Policy of 1918-1921}

In 1918, as soon as Georgia was liberated from the Russian Empire and gained independence, the Ministry of Public Education was established to leverage the results of Russificationist policies, to establish national values, and to promote democratic and European values. Consequently, radical and large-scale reforms were implemented by Georgian reformers in the education system.

At the initiative of Georgian reformers, the Ministry of Public Education started to organize the Georgian educational system according to the European model. One of the first steps taken by the Ministry of Public Education was to establish a universal, compulsory and free education system based on Western values. Along with the principle of universality, the Ministry of Public Education implemented a major reform towards school unity and implemented a tightly integrated system of primary and secondary education aimed at preparing students for higher education. Equalization of universal and compulsory education with European standards (Gavashelishvili, 2004) would be impossible in the conditions of existing 
schools. Therefore, it was necessary to increase the number of schools. As a result of the reform, if in 1914 there were 864 schools in Georgia with 80,000 students, in 1920 the total number of schools doubled and consisted 1,924 schools with 162,000 students (Bendianishvili, 2001).

In parallel with the increase in the number of schools, there were implemented the reform of nationalization of schools. The changes included the Georgianization of educational programs and manuals, as well as retraining of teachers and the development of national terminology. The intensification of the topic of nationalism has put the issue of education for the representatives of national minorities on the agenda. Georgia, liberated from the colonial yoke, was given a reality caused by the artificial migration, where the share of Georgians in the total population decreased by $10 \%$ during the Russian Empire and amounted to 69\% (Janelidze, 2008, p. 55). As soon as Georgia declared independence, it recognized the rights of national minorities and created non-Georgian-language sectors in schools, as well as opening nonGeorgian-language schools. According to the data of 1919, out of 1,860 primary schools in Georgia, 120 were non-Georgian (Bendianishvili, 2001, p. 262). As for the proclamation of Georgian as the state language in the Republic of Georgia, this news was met with great opposition from ethnic minorities (Bendianishvili, 2001, p. 259) as a result, according to the law adopted on October $1^{\text {st }}$ of 1918 , about the state language, members of national minorities were allowed, if they did not know the state language, to pronounce the word in native language (Kobakhidze et al., 2018, p. 32).

The Georgian reformers and educators were highly interested in the tendencies ongoing in European educational space regarding teachinglearning theories, arrangement of the educational system, the values and approaches. Georgian educators were looking for a base in the minds of European educators. From the articles and publications published in the Georgian press, it is clear that the main focus in Georgia at that time was on the political partner of the country - the German education system, as well as the ideas and theories of Maria Montessori, Helen Parkhurst, Friedrich Froebel (Modebadze, 2009), John Locke, Jean-Jacques Rousseau (Sekhniashvili, 1917) and other European educators were well liked.

Arranging the democratic values of the country's education system also meant a change in the strictly centralized system of governance. It is noteworthy that in 1918-1921, teachers' unions and individual pedagogical groups were given a free space for implementing the wide range of activities. At the initiative of the Teachers' Union, the issue of school autonomy was put on the agenda, when it was determined that "teachers, inspectors and principals should be nominated by pedagogical councils and approved by the government" (Bendianishvili, 2001, p. 264). With the support of the 
pedagogical groups of Western and Eastern Georgia, the issue of school autonomy in the country became a part of the ongoing reforms of that time.

The radical nature and scale of the education reform of 1918-1921 came from the idea of a complete change in the legacy of centuries-old Tsarist Russia's Russificationist policies. Educational reform was aimed at establishing universal and democratic values in education by creating a universal, compulsory, free, and unified school system, where the educational process was conducted in Georgian, based on national principles and European educational theories and approaches. Given the socio-political situation in the country, it became impossible to continue reforms in the long run, however, the reform of 1918-1921 clearly defined the course chosen by the country towards democratization.

\section{Soviet educational policy}

The overthrow of the tsarist government in the Russian Empire and the replacement of the tsarist autocracy with the Soviet Union were followed by revolutionary changes in the social, political, or economic arrangement of the country. The education system was no exception. Education played a key role in the construction of a new socialist state in the Soviet Union. It had to change the human mind and form an ideologized society.

Compulsory general education were introduced throughout the Soviet Union to implement the party ideas of the Bolshevik government. The main goal of the party was to resolve the issue of illiteracy. As of 1917 , only $24 \%$ of the 50 different nationalities and 100 different languages spoken in the Russian Empire were literate. The current situation posed a great threat to the Bolshevik government, which was based on Lenin's doctrine: "Without teaching there is no knowledge and without knowledge there is no communism" (Chabe, 1971, pp. 525-531). Therefore, as a result of large-scale reforms in the Soviet Union, according to state data, the literacy rate increased to $54 \%$ in 1920 , to more than $80 \%$ in 1939 , and in the 1960 s the Soviet government claimed to have 100\% Rate (IQASGA, 2008, p. 5).

In order to increase literacy in the society, the government implemented an important reform of the native language of different peoples of the Soviet Union, which meant preserving the native language for the member states. However, it should be noted that Soviet policy was based on the idea "national form and socialist content" (Chabe, 1971, pp. 525-531), which meant that national minorities could maintain their own language, literature, art, music, dance, culture, however, a necessary condition for the content to be socialist, communist ideas, values and goals. However, the Soviet government also came up with the idea of abolishing the status of the state language, which was followed by a large wave of protests in Georgia in 
1978, and as a result, the government withdrew and failed to implement its own initiative.

In the construction of the new state in the Soviet Union, socialist pedagogy, based on the teachings of Karl Marx and Friedrich Engels on the upbringing, teaching and education of the adolescent generation, was vital. The concept of adolescent upbringing in the Soviet Union was based on V. Lenin's doctrine of communist upbringing. The concept of upbringing was based on proletarian morality, which included loyalty to the people, friendly fellowship, discipline, public property, liberation from the captivity of individualism, and personal interests in the collective (Vasadze, 1988, p. 151). Lenin considered the school to be the party's policy-maker, who would shape the youth in the spirit of loyalty to the party and the people. He noted that "we clearly declare that school without life, without politics, is a lie and hypocrisy" (Vasadze, 1988, p. 401).

The approach of the Soviet authorities towards the implementation of reforms is important. In the conditions of centralized and autocratic management of school education, the issue of implementing the government's policy was controlled at the highest level. The practice of using propaganda to support specific initiatives or to instill anti-Western sentiment in the population was high. The practice of public disclosure during the Soviet period, which was actively used in the event of an unsuitable event for the system, is also important. The most serious manifestation of mass control by the government was the period of rapid reform in the field of education under Stalin, when the activities of teachers, students and, moreover, parents were actively monitored. In the event that a student exhibits inappropriate behavior for the system, the responsibility lies with the school leadership, teachers, and parents (IDFI, 2019).

The nature of Soviet politics was characterized from Stalin's totalitarian to authoritarian socialist model of Khrushchev and Brezhnev. The form of authoritarian education in schools was presented in a direct way, which was to integrate party ideas into both educational policy and its social intervention in society. After Tsarist Russia, the benefits of education in the Soviet Union are undeniable, however, people paid for it on the basis of ideological upbringing.

\section{Modern educational policy of Georgia}

After Georgia's withdrawal from the Soviet Union and the restoration of independence, a major wave of reforms began, aimed at the complete elimination of Soviet heritage on the one hand and the orientation of Western values on the other.

Reforms in the education system in Georgia are presented in several stages. Initially, the reforms began with "Georgian Forces and Georgian 
Orientation" (Chkuaseli et al., 2014, p. 260), which was characterized by unsuccessful initiatives (Goglichidze, 2010). The next wave of reforms began the process of bringing the Georgian education system closer to Western values. There was a sense of protest in some parts of the society. There was an opinion that the reform was destroying Georgian and national peculiarities and arranging the entire educational system according to the orders of the donor organizations. However, later in the Georgian educational policy the relevant national interests and values were clearly defined. The National Goals for General Education was developed, which stipulated that "school education should develop the ability of adolescents to properly define the state, cultural, economic and political interests of their own country and enable them to make good decisions and take active action" (NGGE, 2004). The National Curriculum, the Law of Georgia on General Education and the Law on the State Language (2015) were adopted, the State Chamber of the Georgian Language (1997) and later the State Language Department (2017) were also established.

Within the framework of the project of Transformation and Strengthening of the Education System of Georgia, the process of introducing democratic values into the Georgian educational space has begun. The legislation prioritizes the inclusion of the Georgian general education system in the international educational space (LGGE, 2005, Article 3). The changes were made in accordance with the European Educational Standards of the Legislative Base, as well as with the changes in the financial and administrative arrangement of the system, the content of teaching and learning and theoretical approaches. Georgia has been actively involved in international educational research PIRLS, TIMSS, PIZA, which confirms its readiness to strengthen the importance of education and to take its place in the European educational space.

From the theoretical point of view of teaching-learning, it is noteworthy that the National Curriculum has defined the focus on the constructivist educational concept, which considers the student in the center of the learning process and where the teacher is assigned the function of consultant and facilitator. The pillars of the Georgian educational system in the modern period are humanistic, social-cognitive, moral developmental, multiple intelligence and socio-cultural educational theories, along with the pedagogical concepts of Jean Piaget, John Dewey, Maria Montessori and Dimitri Uznadze. The need to integrate these philosophical and theoretical currents into the learning process is determined by the National Curriculum, as well as the professional standards and qualification requirements of school principals and teachers. It is on the basis of these modern theories and approaches that the process of transforming Georgia's teaching-learning into democratic values is underway. 
One of the key steps in moving towards European and democratic values was to escape the strictly centralized and authoritarian management practices of the Soviet legacy and move to a decentralized management style. To do this, boarding schools have been set up in schools to establish democratic principles of participation and representation. Also, with the introduction of voucher funding, the issue of financial autonomy of schools was defined, and the granting of freedom of choice to parents was strengthened by neo-liberal approaches to education in order to strengthen the principles of accountability.

In order to free Georgia from its Soviet legacy, it had to carry out radical and large-scale reforms aimed at establishing democratic values and principles. Accordingly, the principles of management of the educational system, as well as teaching and learning, were based on the theoretical constructs and views prevailing in the international educational space in the interests of the state.

\section{Research Findings}

The research has found significant common and distinctive features of Tsarist and Soviet policies on the one hand and the first independent republic of Georgia of 1918-1921 and modern Georgia on the other, in the direction of the importance of education, state language policy, management systems and theoretical foundations of teaching and learning.

\section{The importance of education}

The issue of education has had a rather negative impact on Tsarist Russia. It was artificially demonized and linked to the notions of anarchism, nihilism, and terrorism (Roucek, 1958). Since low-grade education was seen as a threat to the existing social order, education was not promoted in the country. Compared to Tsarist Russia, education in the Soviet Union acquired a completely different meaning. As a result of the task of building a new socialist state for education, the education of the masses has become a necessary factor for the formation of a proletarian society and the spread of party ideology among the people.

Education played an extremely important role in the first independent republic of Georgia. Its importance was taken to the importance of statehood, and therefore, with the declaration of independence, great emphasis was placed on eliminating the practices of old, tsarist Russia, establishing national values and arranging the Georgian education system according to new, Western values and democratic principles. Like the First Republic, the educational reforms carried out in independent Georgia since 1991 were characterized by a radical nature aimed at liberating the old Soviet school 
traditions and establishing democratic values and integrating them into the international educational space.

\section{National language policy}

The policy of the state language was the biggest pressure during the Russian Empire. The Russificationist policy of tsarism was aimed at eradicating the national culture in order to obtain from the peoples of the empire the Russian language, customs and beliefs. A different strategy from Tsarist Russia was used in the Soviet Union. The Soviet government pursued a policy of national form - socialist content that allowed countries to preserve their native language, culture, music, dance, art and literature. However, the necessary condition was that everything be subject to socialist and ideological principles.

The policy of the national language in the first independent republic of Georgia was not only educational, but also equal to the existence of the state. Accordingly, from the development of state language policy to the issues of schooling, teacher training, and terminology, it has been the subject of the highest interest in the first independent republic of Georgia. In modern times, the state language has been regulated by the legislative framework, which has given the Georgian language the status of historical and cultural heritage, the protection of which is considered a necessary condition of statehood and is protected by the Constitution.

\section{Management style}

Tsarist Russia, in the style of autocratic and tyrannical rule, demonized education, persecuted and destroyed all manifestations of democratic ideas and liberalism. "Autocracy, Orthodoxy, and Nationalism" (Roucek, 1958, p.43) put Russia in complete isolation from Western civilization. During the Soviet era, public exposures and, most importantly, the use of the death penalty were used by the government to establish a civilization of fear, which controlled not only the educational system, but also all aspects of public life. In the first independent republic of Georgia, as soon as it was established, it was announced that the state course was aimed at democratization, the establishment of Western values. The education system was based on the German model and introduced approaches to European education. The issue of management autonomy was presented in various aspects of the work of Georgian schools. In the modern Georgian state, the inheritance of the decentralized system of governance has shifted from the legacy of high centralization characteristic of the Soviet system. With the introduction of the Board of Trustees of the High Self-Government School and voucher funding, democratic approaches to freedom of choice, participation, representation, 
publicity and accountability were introduced into the system and the autonomy of schools was increased.

\section{Theoretical approaches to teaching-learning}

Tsarist Russia has resorted to the classical-conservative model of education in schools. Scholastic and dogmatic teaching was practiced in schools. Consequently, a strict regime, listening practices, neglect of the child's nature, and physical punishment practices prevailed. The learning process was teacher-centered, with students demanding wordless obedience. The establishment of communist morality through obedience was the goal of Soviet pedagogy in the Soviet Union. Marxist pedagogy relied heavily on the theory of upbringing to implement the policy of forming an ideologized society.

As soon as Georgia gained independence, the European education system became the focus of the Georgian education system. The Georgian education system was based on the German model and Western values about individual freedom, independence, self-regulation and creativity were transferred. The student-centered learning environment focused on student motivation, empathy, play methods, and experiential learning approaches. The educational policy developed after 1991 also recognizes Western philosophical approaches based on the philosophy of constructivism, which defines the principles of student-centered learning-teaching. These periods are united by the views of John Dewey, Maria Montessori and Dimitri Uznadze. The teaching-learning of the modern period is based on the theoretical views adopted in Georgia in 1918-1921 on the uniqueness of the person, the ability of continuous human development, sincerity, unconditional positive attitude and, in general, the harmonious upbringing of an independent and free person.

\section{Conclusion}

In conclusion, the formation of the Georgian education system from Tsarist Russia to the first independent republic of Georgia of 1918-1921 and later from Soviet Union to modern Georgia has been the subject of thorough examination in four main directions regarding the importance of education, state language policy, management systems and theoretical foundations of teaching and learning. For the four periods of development of the Georgian education system, the main concepts related to the above concepts and their cross-grouping with the Soviet system of the Tsarist Empire and the system of the First Republic with the education systems of modern Georgia were identified. The comparison of the presented periods and the identification of common and distinctive features, the determination of the strategies and motives of the authorities, which had a significant impact on the formation of the Georgian education system, were carried out. 
Georgia's education system has had to alternate between the Russian Empire and then the Soviet government. Accordingly, it reflected the characteristics of both systems. Despite the distinguishing marks between the approaches of the tsarist and Soviet authorities regarding education, for the subjugated countries they pursued the same policy towards the idealization of the Russian people and the enslavement of other peoples. If Tsarist Russia did so by harsh methods, the Soviet Union chose relatively soft tactic to eliminate national values and spread its own ideology. With a centralized and controlled system of governance, both systems of fear appealed to civilization - on the one hand, to achieve imperial and on the other hand Soviet party goals. The strict school regime, the practice of corporal punishment, the method of assimilation, the teacher-centered and authoritarian approaches were the unifying features of both systems.

The Georgian people had to escape from the self-imposed values of the above-mentioned systems at the cost of selfless struggle. The liberation of the country from both Tsarist Russia and the Soviet Union was followed by a difficult socio-economic situation, and it was in these difficult conditions that the country had to implement its own ideals for education. An important circumstance is the fact that the orientations of the first independent republic of Georgia and the educational policy of modern independent Georgia coincide. Despite the 100-year gap, the Georgian people's choice of Western values, democratic principles and European philosophical currents of teaching and learning, and membership in the international educational space, coincide. Therefore, it can be concluded that if not for the Russian policy of violence, the Georgian people and the Georgian education system would have been a member of the European educational space for centuries.

\section{References:}

1. Bendianishvili, A. (2001). Sakarvelos pirveli respublika 1918-1921 [The first republic of Georgia in 1918-1921]. Scientific Academy of Georgia Iv.Javakhishvili Institute of History and Ethnology.

2. Chabe, A.M. (1971). Soviet educational policies: Their development, administration, and content.The Instructor Publications, 525-531.

3. Chkuaseli, K., Sanadze, R. \& Qitiashvili, Z. (2014). Zogadi ganatlebis reforma saqartveloshi - Istoriuli rakursi/1991 tslidan dghemde/ [The reform of general education in Georgia - Historical review (1991 present). Education Science and Psychology, 5(31),259-273.

4. Gavashelishvili, A. (2004). Saqartvelos respublikis erovnuli saganmanatleblo politika 1918-1921 [National education policy of the republic of Georgia in 1918-1921].Tbilisi.

5. The Georgian Historical Essays. (1972). SaqarTvelo 1900-1921 tslebshi [Georgia in 1900-1921]. Soviet Georgia. 
6. Goglichidze, A. (2010). Saqartvelos zogadi ganatlebis systemis mdgomareobisa da martvis analizi [The analysis of the general education system and its management in Georgia]. Policy and Management Consulting Group.USAID Georgia.

7. Institute for Development of Freedom of Information. (2019). Stalinizmi sabchota skolebshi da skolis moscavleebis saqme [Stalinism in Soviet schools and students cases] https://idfi.ge/ge/stalinism_in_soviet_schools.

8. International Qualifications Assessment Service Government of Alberta. (2008). International education guide for the assessment of education from the former USSR and the Russian federation. https://www.alberta.ca/documents/IQAS/russia-internationaleducation-guide.pdf

9. Janelidze, O. (2018). Saqartvelos demokratiuli respublikis istoriis narkvevebi [The historical essays about the democratic republic of Georgia]. The National Library of Parliament of Georgia.

10. Karichashvili, D. (1917). Skolebis gakartuleba [Georgianization of schools]. Scientific Pedagogical and Literature Journal Ganatleba, 67, 345-347.

11. Kobakhidze, B., Silakadze, D. \& Vacharadze, A. (2018). Saqartvelos pirveli respublika [The first republic of Georgia]. Ministry of Justice of Georgia and National Archive of Georgia.

12. Laskhishvili, G. (1928). Memuarebi [Memoirs](1885-1915).

13. Laskhishvili, G. (1918). Saqartvelos erovnul sabchos [Speech to the national council of Georgia]. Scientific Pedagogical Journal Ganatleba, 1, 70-72.

14. Law of Georgia on General Education (2005). https://matsne.gov.ge/en/document/download/29248/56/en/pdf

15. Modebadze, N. (2009). Evropuli ganatlebis gavlena saqartvelos saganmanatleblo sistemaze saqarTveloshi demokratiuli sazogadoebis sheqmnis periodebshi [The influence of European education on Georgian education system in the period of developing democratic society in Georgia] (1918-1921 and 1991-2009). International Scientific Journal Inteleqti, 2 (34), 244-245.

16. Oboladze, U. (1953). Akaki Tsereteli (1840-1915) Sakhalkho ganatlebis qartveli moghvatseebi da sakhalkho mascavleblebi [Georgian public figures and teachers of people's education]. http://nateba.websail.net/biographies/180-tsereteli-ak

17. Ordinance of the Government of Georgia \#84. LHG, 122, 29/10.2004. The National Goals of General Education.

18. Roucek, J.S. (1958). Education in czarist Russia. History of Education Journal, 9 (2), 37-45. 
19. Sekhniashvili, K. (1917, April-May). Genkeli G.khalkhis ganatleba, misi mnishvneloba, mizani da sashualeba [Genkeli G. on people's education, its importance, goals and objectives]. The Scientific Pedagogical and Literature Journal Ganatleba, 251-259.

20. Vasadze, N. (1988). Pedagogikis istoria [The history of pedagogics]. Ganatleba. 